\title{
Viral infections and wounds
}

\author{
Naznin Karsan MSc MD, Ronald M Zuker MD FRCSC FACS \\ Division of Plastic Surgery, The Hospital for Sick Children, Toronto, Ontario
}

\begin{abstract}
N Karsan, RM Zuker. Viral infections and wounds. Can J Plast Surg 1998;6(3):159-161.
The effects of viral infections on normal wound healing are discussed. The case report presented suggests that viruses can have a detrimental effect on the normal wound healing process.
\end{abstract}

Key Words: Viral infections, Wound healing

\section{Infections virales et plaies}

RÉSUMÉ : On aborde ici les effets des infections virales sur le processus normal de cicatrisation des plaies. Le rapport de cas présenté suggère que les virus peuvent exercer un effet nuisible sur ce processus.

$\mathrm{T}$ he effects of viral infections on wounds, be they surgical or due to thermal injury, remain ill-defined. The purpose of this paper is to describe briefly the effects of surgical wounds, burn wounds and viral infections on the immune system and to review what has been reported in the literature on viral infections and wounds in the immunocompetent host to gain a greater understanding of their tentative relationship.

To illustrate the importance of viral infections on a surgical wound, the case of a young boy who developed chickenpox postoperatively leading to significant wound disruption is reported.

\section{CASE PRESENTATION}

A 13-year-old boy presented with a congenital giant hairy nevus, which extended from the upper back to the midbuttock region and coursed laterally to each flank and the lower anterior abdominal wall. He also had numerous other smaller congenital nevi on the scalp, face, arms and legs. Because of a questionable nodule in his midback, a large transverse ellipse was excised when he was one year of age. Histology demonstrated that the lesion was benign. At age three years, the patient underwent tissue expansion with excision of a large segment of the back nevus without complication. In May 1995, further tissue expansion was undertaken. Expan-

Correspondence and reprints: Dr RM Zuker, 555 University Avenue, Toronto, Ontario M5G 1X8. Telephone 416-813-1500, fax 416-813-6447, e-mail ronald.zuker@sickkids.on.ca sion progressed as planned (Figure 1), and the expanders were removed on July 10. A large segment of the nevus was excised with resurfacing by using the expanded back flaps. The patient was known to have been in contact with chickenpox approximately two weeks before the surgery. However, it was thought that he had chickenpox when he was a toddler. On the following day his temperature rose to $39^{\circ} \mathrm{C}$, and he developed a rash on his shoulders and arms. This rash rapidly coalesced into vesicle formation, and chickenpox was diagnosed. The patient remained febrile. On inspection of his wound on July 14, the central portion was seen to have dehisced. Wound breakdown progressed, leaving a large open area with the vesicular eruption most intense at the wound margins. The dressings were changed, and the wound was sufficiently clean to accept a split thickness skin graft on July 27. Following the skin graft, wound healing progressed satisfactorily. He is currently fully active with no limitation of movement but with an obvious large skin graft in his central back, which will require reconstruction.

\section{DISCUSSION}

Repair of surgical incisions involves the process of healing by first intention. Incision results in the death of a limited number of epithelial and connective tissue cells as well as disruption of the continuity of epithelial basement membrane. The space formed by the incision immediately fills with clotted blood containing fibrin and blood cells. Neutrophils are the first inflammatory mediators that move towards 


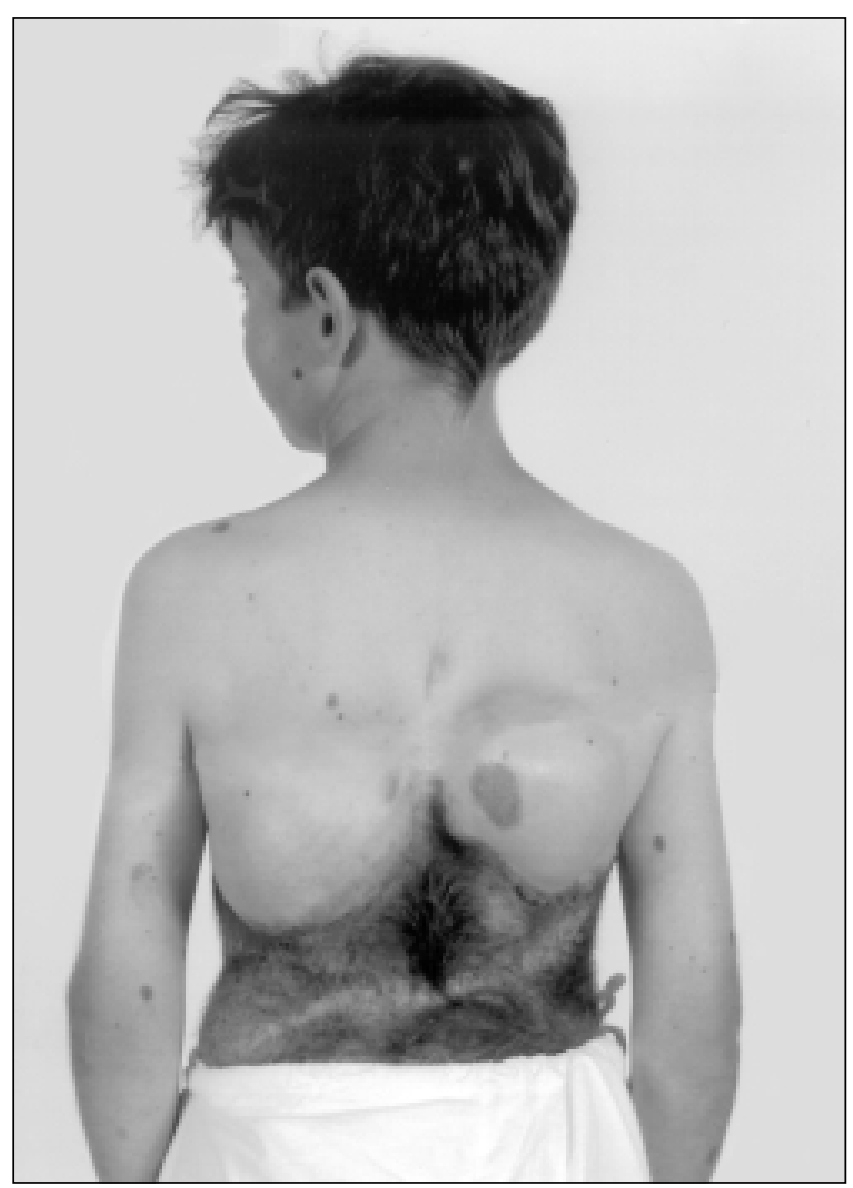

Figure 1) Congenital giant hairy nevus with tissue expanders fully inflated just before surgical removal

the fibrin clot. By postoperative day 3 , neutrophils are largely replaced with macrophages resulting in the formation of granulation tissue. Concomitant with neutrophilic migration to the wound, the epidermis undergoes thickening at the wound edges due to the increased mitotic activity of basal cells. This sequence of events summarizes the inflammatory reaction involved in the early stages of wound repair by first intention (1). Burns, on the other hand, differ from surgical wounds. The devitalized tissue undergoes coagulative necrosis, and the adjacent vital tissue develops marked exudation. However, the adjacent vital tissue also accumulates inflammatory cells (1). Thus, both surgical wounds and burns sequester inflammatory mediators initially.

The inflammatory reaction that develops at the site of surgical wounds and burns differs markedly from the immune system's reaction to viral infection. The immune reaction to viruses involves both natural and specific immune responses. Two principle mechanisms are involved in natural immunity against viruses: stimulation of type I interferon by virally infected cells and lysis of virally infected cells by natural killer (NK) cells. It is noteworthy that type I interferon enhances the ability of NK cells to lyse virally infected target cells (2). Specific immunity to viruses is mediated by a combination of humoral and cellular mechanisms. Humoral immunity plays a key role in the early phase of viral infection (before the micro-organisms have gained entrance to the host cells) to enhance phagocytic clearance of viral particles through opsonization and for complement activation. Cytotoxic T lymphocytes (CTLs) are the cells primarily responsible for specific immunity against established viral infection. CTLs have potent antiviral effects as a result of their ability to lyse infected cells and stimulate intracellular enzymes that degrade viral genomes, and because they secrete cytokines with interferon activity. Thus, while antibodies of the humoral immune system act to block viral binding and entry into host cells, CTLs inhibit viral replication in infected cells (2).

Experimental evidence supports the theory that viral infection plays a detrimental role in wound healing; delayed and disturbed wound healing were reported in the oral cavity of rats infected with herpes simplex virus type 1 (HSV-1) (3). Treatment of the HSV-1-infected rats with the antiviral agent acyclovir resulted in a decrease in the degree of inflammation and improved healing in the infected wounds (3). Moreover, studies in virally infected mice revealed that wound healing could be delayed due to viral alteration of macrophages (4). Although both neutrophils and macrophages play a role in wound repair as described earlier, experimental studies have shown that the repair process is not dependent on the presence of neutrophils except in grossly infected wounds (5). However, the absence of macrophages was demonstrated to inhibit normal wound healing (6). Viral alteration of macrophages, therefore, has significant implications in wound healing.

Surgery per se, in addition to host immunosuppression, trauma, malnutrition or sepsis, may play a role in reactivation of a previously dormant virus. Evidence to support the effect of surgery was demonstrated with the reactivation of HSV-1 (7-9) and human papilloma virus (HPV) (10) following surgery. Reactivation of the virus was attributed to the direct stimulation of peripheral nerves during surgery. Authors of the HPV study suggest that injury or destruction of cells during surgery may result in the release of viral material residing within the host cell and the subsequent viral reactivation observed (10).

Viral burn wound infections have been reported to be very rare (11-17). As with surgical wounds, thermal injuries destroy the barrier function of skin, enabling the passage of viruses (18). However, immunological changes in the burn population are much more significant and widespread. The effects of burns on the immune system include decreased neutrophil chemotaxis, phagocytosis (19) and killing ability (19). In addition, decreased macrophage activity (18), lymphocyte response to mitogen stimulation (20) and gamma globulin (21) have been reported. Furthermore, cell-mediated immunity has been shown to be impaired during the postburn period (22). Moreover, cell-mediated immunity is believed to be the most important host defense against viral infection (22).

The paucity of reported cases of viral infection and burns is intriguing in light of the immunocompromised state of the burned patient. Studies in pediatric burn patients have demonstrated the concurrent presence of cytomegalovirus (CMV) 
$(18,23)$, HSV $(18,23)$, adenovirus (23) and varicella (13). Viral infection usually manifests itself by small vesicles in re-epithelializing second-degree burns and split thickness skin graft donor sites followed by a loss of superficial epithelium. It was hypothesized that the susceptibility of such reepithelializing areas to lesions characteristic of viral infection may be due to the presence of nucleoprotein moieties produced by regenerating epidermal cells that could potentially be used for viral replication (13). Alternatively, the presence of lesions in and around the wound may be due to a thin, readily inoculated integument (13). Secondary bacterial infection has been reported to occur two to three days after clinical manifestations of viral infection (18). It was not determined whether the viral infection predisposed the wound to the subsequent bacterial infection (18). However, most viral infections are self-limiting, resolving themselves within approximately 10 days (18).

The self-limiting nature of viral infections was confirmed

\section{REFERENCES}

1. Kumar V, Cotran RS, Robbins SL. Basic Pathology, 5th edn. Philadelphia: WB Saunders Company, 1992.

2. Abbas AK, Lichtman AH, Pober JS. Cellular and Molecular Immunology. Philadelphia: WB Saunders Company, 1991.

3. Hedner E, Vahlne A, Hirsch JM. Primary herpes simplex virus (type 1) infection delays healing of oral excisional and extraction wounds in the rat. J Oral Pathol Med 1990;19:471-6.

4. Kenyon AJ. Delayed wound healing in mice associated with viral alteration of macrophages. Am J Vet Res 1983;44:652-6.

5. Simpson P, Ross R. The neutrophilic leukocyte in wound repair: a study of antineutrophil serum. J Clin Invest 1971;51:2009-10.

6. Ross R. The fibroblast and wound repair. Biol Rev 1968;43:51-96.

7. Kameyama T, Haikata K, Nakamura Y, Murase H, Yamamoto S. Shedding of herpes simplex virus type 1 into saliva after surgery for oral and genital or urological cancer patients. Kurume Med J 1989;36:117-21.

8. Nesburn AB, Kickinson R, Radnoti M, Green MJ. Experimental reactivation of ocular herpes simplex in rabbits. Surv Ophthalmol 1976;21:185-90.

9. Porteous C, Bradley JA, Hamilton DN, Ledingham IM, Clements GB, Robinson CG. Herpes simplex virus reactivation in surgical patients. Crit Care Med 1984;12:626-8.

10. Bergstrom LV. Laryngeal papillomatosis: recurrence after 33-year remission. Laryngoscope 1982;92:1160-3.

11. Bruck HM, Nash G, Foley D, Pruitt BA Jr. Opportunistic fungal infection of the burn wound with phycomycetes and aspergillus. Arch Surg 1971;102:476-81.

12. Betts RF, George SD, Bundell BB. Comparative activity of immunofluorescent antibody and complement-fixing antibody in cytomegalovirus infection. J Clin Microbiol 1978;4:151-6.

13. Foley FD, Greenwald KA, Nash G, Pruitt BA Jr. Herpes virus infection in burned patients. N Engl J Med 1970;282:652-6. by the observation that CMV infection among patients with burns did not contribute to the mortality or morbidity of burns, either directly or indirectly (24). Nonetheless, viremia has been reported to occur (13).

As yet, significant problems with viruses have not been encountered (or identified) in surgical or burn patients; however, further investigation is required (25). This case report is offered as evidence of the detrimental effects of the chickenpox virus on a surgical wound. Viral infections of surgical and burn wounds may be more prevalent than the few reported cases in the literature indicate. Viral infection comprised $23 \%$ of nosocomial infections during a fouryear period in a university pediatric hospital (26). Increased clinical suspicion of viral infection may facilitate its diagnosis and improve the management of postoperative patients and burn victims because treatment that can alleviate symptoms and reduce the likelihood of spread of infection is available (27).

14. Nash G, Asch MJ, Foley FD. Disseminated cytomegalic inclusion disease in a burned adult. JAMA 1970;214:587-9.

15. Nash G, Foley FD. Herpetic infection of the middle and lower respiratory tract. Am J Clin Pathol 1970;54:857-63.

16. Nash G. Necrotizing tracheobronchitis and bronchopneumonia consistent with herpetic infection. Hum Pathol 1972;3:283-91.

17. Seeman J, Konigova R. Cytomegalovirus infection in severely burned patients. Acta Chir Plast 1976;18:142-51.

18. Luterman A, Dacso CC, Curreri PW. Infections in burn patients. Am J Med 1986;81(Suppl 1A):45-52.

19. Alexander JW, Ogle CK, Stinnett JD, MacMillan BG. A sequential prospective analysis of immunologic abnormalities and infection following severe thermal injury. Ann Surg 1978;188:809-16.

20. Miller CL, Baker CC. Changes in lymphocyte activity after thermal injury. The role of suppressor cells. J Clin Invest 1979;63:202-10.

21. Lanser ME, Saba TM, Scovil WA. Opsonic glycoprotein (plasma fibronectin) levels after burn injury: relationship to extent of burn and development of sepsis. Ann Surg 1980;192:776-82.

22. Munster AM, Eurenius K, Katz RM. Cell-mediated immunity after thermal injury. Ann Surg 1973;177:139-43.

23. Linnemann CC, MacMillan BG. Viral infections in pediatric burn patients. Am J Dis Child 1981;135:750-3.

24. Bale JF Jr, Kealey GP, Massanari RM, Strauss RG. The epidemiology of cytomegalovirus infection among patients with burns. Infect Control Hosp Epidemiol 1990;11:17-22.

25. Frame JD, Kangesu L, Malik WM. Changing flora in burn and trauma units: experience in the United Kingdom. J Burn Care Rehabil 1992;13:281-6.

26. Ford-Jones EL, Mindorff CM, Langley JM, et al. Epidemiologic study of 4684 hospital-acquired infections in pediatric patients. Pediatr Infect Dis J 1989;8:668-75.

27. Lamey PJ, Lewis MA. Oral medicine in practice: viral infection. Br Dent J 1989;167:269-74. 